\title{
Mast Cells and Angiogenesis in Oral Malignant and Premalignant Lesions
}

\author{
E.Z. Michailidou, A.K. Markopoulos* and D.Z. Antoniades
}

Department of Oral Medicine and Maxillofacial Pathology, Aristotle University, Thessaloniki, Greece

\begin{abstract}
Mast cell contribution to neoangiogenesis during tumorigenesis in oral squamous cell carcinoma is not determined yet. Objectives: To associate numerical mast cell density (MCD) to numerical microvessel density (MVD) during the progression of oral leukoplakia without dysplasia and leukoplakia with dysplasia to squamous cell carcinoma (OSCC). Materials and methods: MVD was analysed immunohistochemically (mouse monoclonal anti-human CD34) in 49 paraffin-embedded specimens, 35 OSCCs, 9 leukoplakias and 5 normal oral tissues. Toluidine blue counterstaining revealed mast cells. MCD and MVD were assessed at the same optical field. Results: MVD increased between: normal oral mucosa, dysplasia ( $\mathrm{p}=0.004)$, OSCC ( $\mathrm{p}=0.001)$, leukoplakia and OSCC $(\mathrm{p}=0.041)$. MCD increased between: normal oral mucosa, dysplasia ( $\mathrm{p}=0.003)$, OSCC ( $\mathrm{p}=0.000)$, leukoplakia and OSCC ( $\mathrm{p}=0.007)$. MVD was found to depend on MCD $(\mathrm{p}=0.000)$ in a percent $28.3 \%$ (power curve fit model). Conclusions: Mast cells are attracted at the lesion site and may turn on an angiogenic switch during tumorigenesis in OSCC.
\end{abstract}

\section{INTRODUCTION}

Mast cells are phylogenetically old, highly granulated cells, already known by their key role in type I hypersensitivity reaction [1]. They are the main effector cells in IgEassociated disorders but also seem to play important roles in acquired or innate host reactions [2]. Mast cells can release numerous pro-inflammatory, immunoregulatory and angiogenic molecules through different stimulation pathways [3]. The activation of mast cells has been proved to have many biological consequences such as mitogenesis, extracellular matrix degradation, angiogenesis and augmentation of microvascular hyperpermeability [4] and recruitment of inflammatory cells including macrophages. It is already known that neoangiogenesis is required for the growth and spread of tumors [5]. Increased angiogenesis has been associated with neoplastic progression, metastasis and outcome in several studies and in a number of malignancies [6-12]. Recent data suggest that the acummulation of mast cells around the tumor margins and their release of potent pro-angiogenic and angiogenic factors may represent a tumor-host interaction which probably favors tumor progression [13-15]. The accummulation of mast cells is usually estimated by counting the mast cell density, which is the number of mast cells per optical field in tissue sections [16]. The contribution of mast cells, however, to angiogenesis during the progression from oral leukoplakia without dysplasia to oral leukoplakia with dysplasia or oral squamous cell carcinoma is not clear yet, due to conflicting results within the literature [14, 17].

The purpose of the current study was to examine the relationship between mast cells, angiogenesis and the histological progression from normal oral tissues through leukoplakia lesions with various degrees of dysplasia to OSCC. We analyzed, therefore, mast cell density and microvessel density in

*Address correspondence to this author at the Department of Oral Medicine \& Maxillofacial Pathology, School of Dentistry, Aristotle University, 54124

Thessaloniki, Greece; E-mail: anmark@ dent.auth.gr oral leukoplakia without dysplasia, oral leukoplakia with mild moderate or severe dysplasia dysplasia and oral squamous cell carcinoma.

\section{MATERIALS AND METHODS}

\section{Tissue Specimens}

Fourty-nine (49) formalin-fixed, paraffin-embedded tissue specimens obtained from oral biopsies, were retrieved from the archives of the histopathology laboratory from the Department of Oral Medicine and Maxillofacial Pathology. The tissue specimens were: 30 oral squamous cell carcinomas, 7 leukoplakias without dysplasia and 12 leukoplakias with dysplasia ( 4 with mild, 4 with moderate and 4 with severe dysplasia). Five samples from normal oral tissue were used as a control group.

In order to focus on the early stages of head and neck cancer, the selection criteria included: Newly diagnosed patients, who visited the Department of Oral Medicine and Maxillofacial Pathology during the period from 2000 to 2007 and invasive squamous cell carcinomas characterized as $\mathrm{T}_{1} \mathrm{~N}_{0} \mathrm{M}_{0}$ or $\mathrm{T}_{2} \mathrm{~N}_{0} \mathrm{M}_{0}$, according to the TNM staging system. The TNM stage was determined after a complete radiographic examination of the patients and the surgical excision of the lesions. The diagnosis was based on the clinical examination and the histopathologic analysis of the specimens. The clinical diagnosis of leukoplakia was given to any white patch or plaque that could not be characterized clinically or pathologically as any other disease or condition such as lichen planus, chronic cheek bite, frictional keratosis, tobacco keratosis, nicotine stomatitis, leukoedema and white sponge naevus. Histopathologically leukoplakia lesions were characterized by a thickened keratin layer of the surface epithelium and/or a thickened spinous layer [18]. The diagnosis of epithelial dysplasia was based on the criteria described in the report from the WHO international collaborating center for oral precancerous lesions [18-20]. 
The recorded clinical and histopathologic data included age, gender, clinical lesion stage, site of the lesion and histopathologic differentiation. The study was conducted according to the Helsinki declaration.

From each paraffin block, two tissue sections, $4 \mu \mathrm{m}$ thick each, were placed on a slide.

\section{Determination of Numerical Microvessel Density}

In order to assess microvessel density, immunohistochemistry staining was conducted. Upon one out of the two tumor sections on each slide, a mouse monoclonal antihuman CD34 Class II antibody (clone QBEnd-10) (Dako Cytomation) (Glostrup, Denmark) was applied. The second tissue section in each slide was stained with anti-mouse $\mathrm{IgG}_{1}$ antibody $\{(\mathrm{mAb}$, Mouse IgG1 (MOPC21), Sigma-Aldrich Co., Steinheim, Germany) $\}$ to serve as an internal negative control. Formalin-fixed, paraffin-embedded human sarcoma Kaposi tissue known to highly express CD34 was used as an internal positive control for the measurements of CD34 expression. Tissue samples were deparaffinized in xylene and rehydrated with graded alcohols. Incubation of the slides in $1 \%$ hydrogen peroxide $\left(\mathrm{H}_{2} \mathrm{O}_{2}\right)$ with methanol for 30 minutes blocked the endogenous peroxidase activity. The slides were then washed with TBS (Triphosphate buffered saline). To retrieve antigen epitopes, tissue sections were heated in citric-acid buffer, at $\mathrm{pH}$ 6.7, for 10 minutes in a microwave oven. The slides were then left to cool at room temperature for 20 minutes. The anti-CD34 antibody was diluted (1:50) and applied on the tissue sections for one hour at room temperature. Immunostaining was then performed using the Envision system (Envision HRP, Mouse/Rabbit detection system) (Dako, Glostrup, Denmark). Afterwards diaminobenzidine chromogen (DAB chromogen) was applied.

\section{Counterstaining with Toluidine Blue for Determination of Numerical Mast Cell Density}

The tissue sections, after the immunohistochemical staining, instead of being counterstained with hematoxylin, they were counterstained with toluidine blue. The slides were quickly dipped 15 times in a $0.1 \%$ tolouidine blue solution and then were washed in tap water to remove excess chromogen. Afterwards, the slides were quickly dipped once in a solution containing $70 \%$ alcohol and $0.5 \% \mathrm{HCl}$ and were dried by firmly pressing them once, against a suitable absorbent paper. They were then washed twice, by 12 dipps each time in xylene and were mounted with entalan. Toluidine blue reveals the mast cells [21,22].

Using this technique, mast cells and microvessels can be observed together at the same slide (Fig. 5). The number of mast cells and microvessels were then counted together, at the same optical field.

\section{Verification of Mast Cell Density Count}

In the above tissue sections, the number of mast cells was counted twice in three optical fields using a magnification x200 (20x objective and $10 \mathrm{x}$ occular lens, $0.785 \mathrm{~mm}^{2}$ per field) and the mean number of mast cells was estimated. Separate tissue sections from the same tissue blocks were stained with toluidine blue alone. The number of mast cells in three optical fields using a magnification x200 was also counted twice and the mean number of mast cells was estimated to ensure that the same number of mast cells were stained using the simple toluidine blue stainining technique and the counterstaining technique.

\section{Numerical Microvessel Density Assessment}

The area of optimal staining for microvessels was marked using a magnification $\mathrm{x} 100$. Within the marked area, at $\mathrm{x} 400\left(40 \mathrm{x}\right.$ objective and $10 \mathrm{x}$ occular lens, $0.785 \mathrm{~mm}^{2}$ per field) magnification and with a one-field depth from the basement membrane of the epithelium or from the tumor invasive margins or from the tumor nests, three microscopic fields, having the larger number of microvessels, were selected and assesed. Microvessel density was defined as the number of stained microvessels per optical field. Any single stained endothelial cell or endothelial cell cluster, clearly separated from adjacent microvessels, tumor cells, and other connective tissue elements was considered a single, countable microvessel [12]. When different degrees of dysplasia were observed at the same tissue section, microscopic fields around the most severe lesion were selected. Necrotic areas, within the tumor sections were avoided.

\section{Numerical Mast Cell Density Assessment}

At the three already selected microscopic fields, having the larger number of microvessels, at $x 400$ magnification and with a one-field depth from the basement membrane of the epithelium, the number of mast cells was counted. Mast cell density was defined as the number of stained mast cells per optical field.

\section{Statistical Analysis}

Statistical analysis using the statistical package SPSS 13 (Chicago, Illinois), was performed. In order to test the differences concerning microvessel density (MVD) and mast cell density (MCD) between any two groups of patients the Bonferoni test, after ANOVA, was used at a significance level of $\mathrm{p}<0.05$. To test if there was a correlation between mast cell density (number of mast cells per optical field) (MCD) and the number of microvessels per optical field (MVD), regression analysis (within the generalized linear models) was performed and the curve fit model was estimated.

\section{RESULTS}

\section{Patients and Tissue Characteristics}

Out of the 49 patients: 36 were men and 13 women. The average age of these patients was $60.38 \pm 14.99$ years, with a range of 26-87 years. Primary tumor sites were: the vermilion border, the buccal mucosa, the tongue, the floor of the mouth and other sites within the oral cavity (Tables 1,2).

\section{Numerical Microvessel Density}

In normal oral epithelium, leukoplakia without dysplasia and leukoplakia with dysplasia lesions, microvessels are mainly located just underneath the epithelium and were stained as brown spots, lines or lumens. MVD was counted in every tissue. In normal oral tissues the mean MVD was 14.08 , in leukoplakia without dysplasia 18.18 , in leukoplakia with dysplasia 21.79 and in OSCC 24.78. The number of microvessels was found to be increased significantly be- 
Table 1. Correlation of MVD and MCD with Patients' Characteristics and Tissue Histopathological Differentiation

\begin{tabular}{|c|c|c|c|}
\hline Histological Diagnosis & Number of Biopsies & \multicolumn{1}{c|}{$\begin{array}{c}\text { Microvessel Density } \\
\text { (Mean } \pm \text { SD) }\end{array}$} & $\begin{array}{c}\text { Mast Cell Density } \\
\text { (Mean } \pm \text { SD) }\end{array}$ \\
\hline \hline Normal & 5 & $14.08 \pm 6.08$ & $1.32 \pm 1.02$ \\
\hline Leukoplakia without dysplasia & 7 & $21.79 \pm 6.20$ & $7.55 \pm 3.26$ \\
\hline Leukoplakia with dysplasia & 12 & $24.78 \pm 8.1$ & $9.11 \pm 3.20$ \\
\hline OSCC & 30 & & $19.92 \pm 5.81$ \\
\hline Grade of Dysplasia & 4 & $19.43 \pm 4.16$ & $7.38 \pm 5.15$ \\
\hline Mild & 4 & $22.38 \pm 3.57$ & $6.86 \pm 2.07$ \\
\hline Moderate & 4 & & $6.15 \pm 3.05$ \\
\hline
\end{tabular}

Table 2. Site of Lesion in Every Histologic Type

\begin{tabular}{|c|c|c|c|c|c|}
\hline \multirow{2}{*}{ Histological Diagnosis } & \multicolumn{5}{|c|}{ Lesion Site } \\
\hline & Vermilion Border & Buccal Mucosa & Tongue & Floor of the Mouth & Other Sites \\
\hline NOM & 2 & 1 & 1 & 1 & 0 \\
\hline Leukoplakia without dysplasia & 2 & 2 & 2 & 1 & 0 \\
\hline OSCC & 8 & 7 & 7 & 5 & 3 \\
\hline \multicolumn{6}{|l|}{ Grade of Dysplasia } \\
\hline Mild & 1 & 1 & 2 & 0 & 0 \\
\hline Moderate & 1 & 2 & 0 & 1 & 0 \\
\hline
\end{tabular}

tween: Normal oral mucosa and leukoplakia with mild $(\mathrm{p}=0.022)$, and severe dysplasia $(\mathrm{p}=0.04)$ and also between normal oral mucosa and OSCC $(\mathrm{p}=0.000)$. The number of microvessels was also found to be increased significantly between: leukoplakia without dysplasia $(\mathrm{p}=0.042)$, leukoplakia with mild $(\mathrm{p}=0.033)$, moderate $(\mathrm{p}=0.010)$, severe dysplasia $(\mathrm{p}=0.04)$ and OSCC, but it was not significantly increased between leukoplakia with severe dysplasia and OSCC $(p=0.262)$ (Table 1, Figs. 1,2,3,4). No correlation was found between the microvessel density and the age of the patients (mean $=22.8$ and $\mathrm{p}=0.30)$ or the site of the primary tumor ( mean $=23$ and $\mathrm{p}=0.247)$.

\section{Numerical Mast Cell Density}

Toluidine blue staining revealed mast cells as large, purple, oval and highly granulated cells (Fig. 5). Mast cells were observed at the lamina propria highly populating areas around the tumor margins. Mast cells were also observed at the tumor periphery and at the stem of the lesion when this existed. Increased numbers of mast cells were also found in areas of high vascularization (namely the 'hot spots'). MCD was counted in every tissue. In normal oral tissues the mean MCD was 1.32, in leukoplakia without dysplasia 4.55, in leukoplakia with dysplasia 7.11 and in OSCC 9.33. The number of mast cells was found to be increased significantly between: normal oral mucosa and leukoplakia with mild $(\mathrm{p}=0.02)$, moderate $(\mathrm{p}=0.011)$ and severe dysplasia $(\mathrm{p}=0.029)$ and also normal oral mucosa and $\operatorname{OSCC}(\mathrm{p}=0.000)$. The number of mast cells was also found to be increased significantly between: leukoplakia with severe dysplasia and OSCC ( $p=0.05$ ) (Table 1 and Figs. 1,2,3,4). No correlation was found between the microvessel density and the age of the patients $($ mean $=22.8$ and $\mathrm{p}=0.30)$ or the site of the primary tumor (mean $=23$ and $\mathrm{p}=0.247)$.

\section{Correlation Between MCD and MVD}

The number of microvessels was found to depend significantly on the number of mast cells $(\mathrm{p}=0.000)$ in a percent $28.3 \%$, following the power curve fit model (Fig. 6). The MVD density can then be estimated by the equation: 
MVD=12.160 x Mast cell density ${ }^{0.283}$. According to this power curve fit model, when the density of mast cells per optical field reached the number of 8 , no further increase in the density of microvessels related to the density of mast cells was observed.

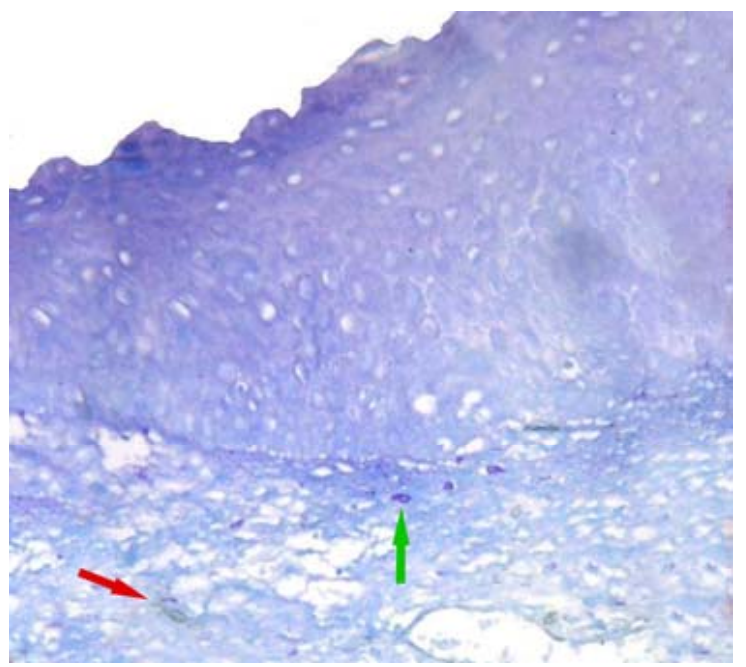

Fig. (1). MVD (red arrow) and MCD (green arrow) were low in normal oral epithelium. (CD34 \& toluidine staining, original magnification X200).

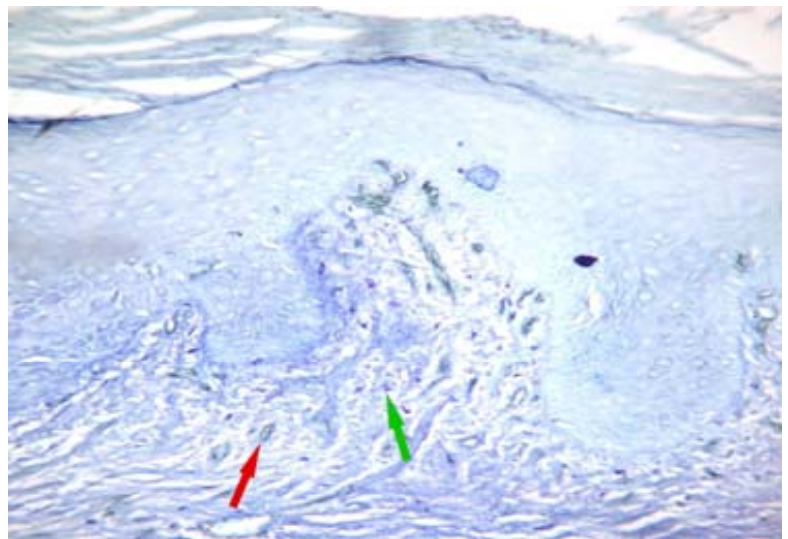

Fig. (2). MVD (red arrow) and MCD (green arrow) were low in oral leukoplakia without dysplasia similar to those of normal oral epithelium. (CD34 \& toluidine staining, original magnification X200)

\section{DISCUSSION}

Solid tumors, in order to outgrow the size of $2 \mathrm{~mm}^{3}$, demand for oxygen supply [23], a fact that makes necessary the formation of new microvasculature [5]. The process of angiogenesis is the outcome of an imbalance between positive and negative angiogenic factors produced by both tumor and host cells. Among the host cells, which produce and release in a considerable quantity pro-angiogenic and angiogenic factors are mast cells [24]. Mast cells are bone marrow derived, highly granulated cells, which are an important source of several proangiogenic and angiogenic factors, such as histamin and heparin [25-27], chymase [28], bFGF (FGF-2) [29, 30], VEGF [31].

TGF-beta [32] and others. Some mast cells can release and then rapidly synthesize VEGF $[33,34]$. Within the oral cavity, the transformation rate of non dysplastic leukoplakia lesions to oral squamous cell carcinoma is estimated up to 0.4-2 \%, whereas the transformation rate of dysplastic leukoplakia lesions up to $9-11 \%$ [35]. The literature about the degree of vascularity and its correlation with mast cells in

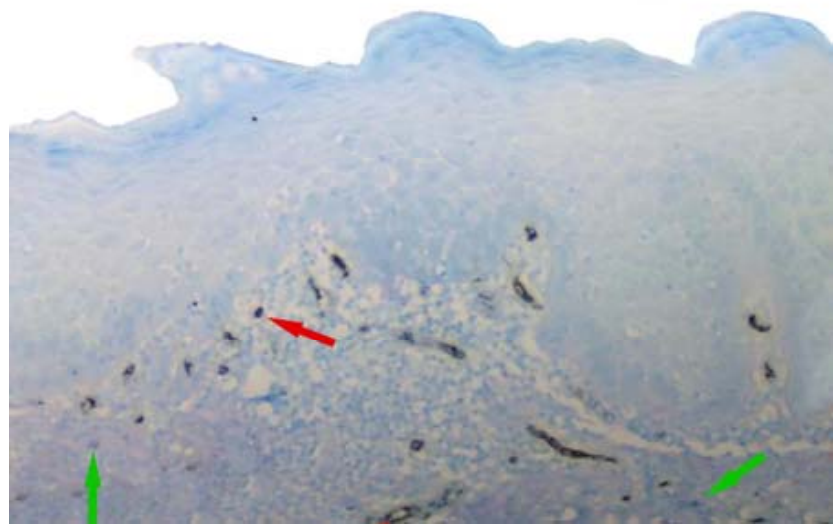

Fig. (3). MVD (red arrow) and MCD (green arrow) were significantly increased in oral leukoplakia with dysplasia. (CD34 \& toluidine staining, original magnification X200).

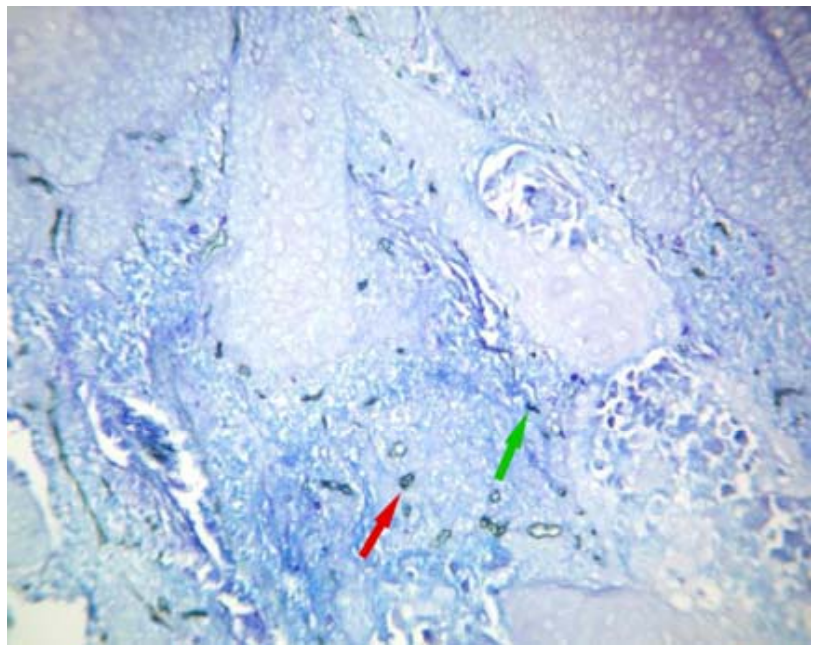

Fig. (4). MVD (red arrow) and MCD (green arrow) were significantly increased in oral squamous cell carcinoma. (Original magnification X200).

premalignant and malignant oral lesions is conflicting [3638]. Most of the reports though, measure mast cells and microvessels in different optical fields making their correlation not warranted [39]. Measuring mast cells and microvessels together, at the same optical field seems a more appropriate approach. In the current study therefore we adopted the counterstaing technique in order to comply with this restrictment. Two other reports $[13,15]$ in the literature also make an attempt towards this idea. In the current study, in order to measure angiogenic activity, a pan-endothelial marker (CD34) was used to mark microvasculature , and a method by Tae et al. [40] rather than the commonly used indirect method of Weidner [41] was adopted in order to count the number of microvessels. Since connective tissue is located just underneath the epithelium it is easier to focus on microvessels, at a $\mathrm{x} 400$ magnification, around the main lesion rather than deep in the connective tissue where diffusion 
of the chromogen is often observed. In the present study, the density of microvessels (MVD) did increase significantly between normal oral mucosa and oral leukoplakia without dysplasia, oral leukoplakia with mild, moderate or severe dysplasia, and oral squamous cell carcinoma. Moreover, the

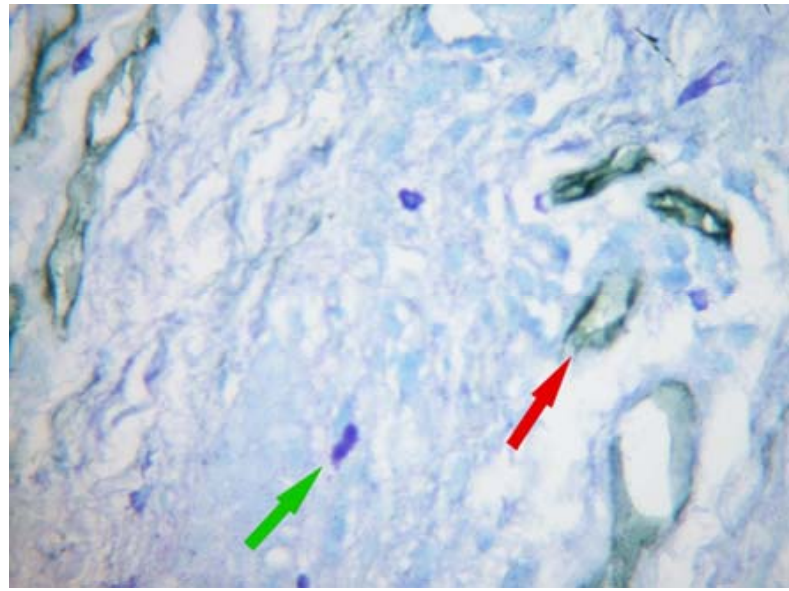

Fig. (5). Mast cell (green arrow) and microvessel (red arrow) revealed with toluidine blue counterstaining (Original magnification $\mathrm{X} 400)$.

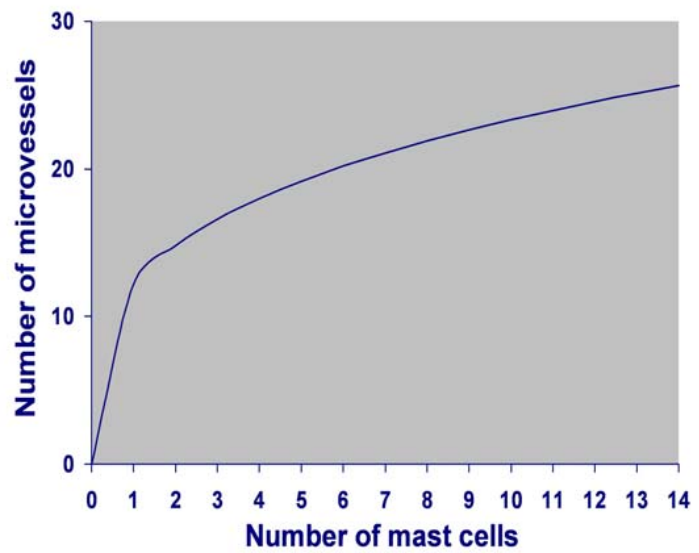

Fig. (6). Power curve fit model depicting the correlation between MCD and MVD.

number of microvessels was found to increase significantly between oral leukoplakia and oral squamous cell carcinoma. Therefore an angiogenic switch seems to be turned on, in these early stages of epithelial malignant transformation. This finding comes into accordance with other reports in the literature [42, 43], stressing the need for thorough research on the possible genotypic and phenotypic alterations resulting in this increased early angiogenic activity and on the role that this early angiogenic activity may play in the mechanisms of epithelial malignant transformation. Moreover, in view of these results, a potentially different therapeutic approach during the progression from normal oral mucosa through leukoplakic lesions with various degrees of dysplasia to OSCC, could be discussed. At the same time, the density of mast cells (MCD) was also found to increase between normal oral mucosa and oral leukoplakia without dysplasia, oral leukoplakia with mild, moderate or severe dysplasia, and oral squamous cell carcinoma elucidating a possible role of these cells during the progression from normal oral tissue to oral squamous cells carcinoma. Several reports on a number of malignancies support the above findings [13, 15, 39] whereas one article so far, concerning oral squamous cell carcinoma, reports the opposite idea [17]. In the current study, the counterstaining technique enabled the simultaneous observation of microvessels and mast cells at the same optical field. Mast cells were found to highly populate areas of dense vascularization (namely the 'hot spots') and especially around the tumor margins. It is also known that mast cells accumulate near sites of new capillary formation whereas direct association of MCs with vascular tube formation was clearly shown in vitro [44]. The number of microvessels was found to correlate significantly with the number of mast cells $(\mathrm{p}=0.000)$ in a percent $28.3 \%$, following the power curve fit model. This correlation is depicted by a certain equation: $\mathrm{MVD}=12.160 \times \mathrm{MCD}^{0.283}$. This finding come into agreement with the results from previous studies in oral squamous cell carcinoma 14], laryngeal squamous cell carcinoma [39] and other malignant tumours such as, squamous cell carcinoma of the oesophagus and lungs [45] and carcinoma of the uterine cervix [46]. According to this power curve fit model, when MCD per optical field reached the number of 8 , no further increase in the number of microvessels related to the number of mast cells was observed. In the current study the mean number of mast cells in leukoplakia with moderate dysplasia was found to be 8.47 which means that theoretically above the point where leukoplakia with dysplasia progresses to OSCC, no further increase in the number of microvessels related to the number of mast cells is present. The correlation of MVD and MCD seems, according to our findings, to be limited only in the early stages of tumorigenesis (during the transition from normal oral tissue through leukoplakic lesions with various degrees of dysplasia to OSCC) before the full transformation of dysplastic lesions to OSCC, giving place to other angiogenic stimuli or factors afterwards. The above findings could come up as a result of the increase in the number of microvessels allowing the infiltration with more mast cells. On the other hand, this direct correlation of MCD to MVD may be due to the proangiogenic and angiogenic activity of mast cells which has been proposed by previous studies [47, 48]. Several factors secreted by mast cells, such histamine [25], heparin [26], VEGF [31], bFGF [29, 30], and tryptase [27], have been shown to exert an activity on the migration and/or proliferation of endothelial cells. The number of stained mast cells depends on the staining technique (toluidine blue, saphranin $\mathrm{O}$, tryptase immunostaining, etc.), with the tryptase immunostaining appearing to be the most specific for human mast cells [49] and the solution used for the tissue-fixing, with Carnoy's solution revealing more mast cells than formalin [50, 51]. Moreover, there is no ideal method or endothelial cell marker, which specifically enumerates active or even all microvessel endothelial cells [12, 40, 41, 52]. It is in fact difficult to measure the number of microvessels and probably even mast cells in tissues [24]. In the present study the counterstaining technique was preferred in order to exert the possible angiogenic activity of mast cells at the same optical field with microvessels. More research with various different methods is needed to establish the above correlations and interactions. 


\section{CONCLUSIONS}

According to the findings of the present study, during the progression from normal oral tissues through leukoplakia with various degrees of dysplasia to OSCC.

1. MVD and MCD seem to be significantly increased.

2. MCD seems to be significantly correlated to MVD.

The authors would like to thank Mrs Penelope Anastasiadou for her technical assistance.

\section{REFERENCES}

[1] Metcalfe DD, Baram D, Mekori YA. Mast cells. Physiol Rev 1997; 77(4): 1033-79.

[2] Puxeddu A, Piliponsky M, Bachelet I, Levi-Schaffer F. Mast cells in allergy and beyond. Int J Biochem Cell Biol 2003; 35(12): 16017.

[3] Crivellato E, Ribatti D. Involvement of mast cells in angiogenesis and chronic inflammation. Curr Drug Targets Inflamm Allergy 2005; 4 (1): 9-11.

[4] Crivellato E, Beltrami CA, Mallardi F, Ribatti D. The mast cell: an active participant or an innocent bystander? Histol Histopathol 2004; 19(1): 259-70.

[5] Folkman J. The role of angiogenesis in tumor growth. Semin Cancer Biol 1992; 3(2): 65-71.

[6] Weidner N, Semple JP, Welch WR, Folkman J. Tumor angiogenesis and metastasis-correlation in invasive breast carcinoma. $\mathrm{N} \mathrm{Engl}$ J Med 1991; 324(1): 1-8.

[7] Tanigawa N, Amaya H, Matsumura M, Shimomatsuya T. Correlation between expression of vascular endothelial growth factor and tumor vascularity, and patient outcome in human gastric carcinoma. J Clin Oncol 1997; 15(2): 826-32.

[8] Xiangming C, Hokita S, Natsugoe S, et al. Angiogenesis as an unfavorable factor related to lymph node metastasis in early gastric cancer. Ann Surg Oncol 1998; 5(7): 585-9.

[9] Ikeda N, Adachi M, Taki T, et al. Prognostic significance of angiogenesis in human pancreatic cancer. Br J Cancer 1999; 79(9-10): 1553-63.

[10] Linder S, Blasjo M, von Rosen A, et al. Pattern of distribution and prognostic value of angiogenesis in pancreatic duct carcinoma: a semiquantitative immunohistochemical study of 45 patients. Pancreas 2001; 22: 240-7.

[11] Yoshij H, Gomez DE, Shibuya M, Thorgeirsson UP. Expression of vascular endothelial growth factor, its receptor, and other angiogenic factors in human breast cancer. Cancer Res 1996; 56(9): 2013-6.

[12] Kyzas PA, Stefanou D, Batistatou A, Agnantis NJ. Prognostic significance of VEGF immunohistochemical expression and tumor angiogenesis in head and neck squamous cell carcinoma. J Cancer Res Clin Oncol 2005; 131(9): 624-30.

[13] Tomita M, Matsuzaki Y, Edagawa M, et al. Association of mast cells with tumor angiogenesis in esophageal squamous cell carcinoma. Dis Esophagus 2001; 14 (2): 135-8.

[14] Iamaroon A, Ponqsiriwet S, Jittidecharaks S, et al. Increase of mast cells and tumor angiogenesis in oral squamous cell carcinoma. $\mathrm{J}$ Oral Pathol Med 2003; 32(4): 195-9.

[15] Elpek G, Gelen T, Aksoy NH, et al. The prognostic relevance of angiogenesis and mast cells in squamous cell carcinoma of the oesophagus. J Clin Pathol 2001; 54(12): 940-4.

[16] Chan JK, Magistris A, Loizzi V, et al. Mast cell density, angiogenesis, blood clotting, and prognosis in women with advanced ovarian cancer. Gynecol Oncol 2005; 99(1): 20-5.

[17] Oliveira-Neto HH, Leite AF, Costa NL, et al. Decrease in mast cells in oral squamous cell carcinoma: Possible failure in the migration of these cells. Oral Oncol 2007; 43(5): 484-90.

[18] Neville BW, Damm DD, Allen CM, Bouquot JE. Oral and Maxillofacial Pathology, 1st ed. Philadelphia, Pennsylvania: Saunders Company 1995; pp. 280-88.

[19] Pinborg JJ, Reichart PA, Smith CJ, van der Waal I. Histological typing of cancer and precancer of the oral mucosa. International Histological Classification of Tumours, 2nd ed: WHO, Geneva 1997; pp. 11-33.
[20] Barnes L, Eveson JW, Reichart P, Sidransky D. Pathology and Genetics of Head and Neck Tumours. WHO Classification of Tumours WHO. 2005; vol. 9.

[21] Sheehan D, Hrapchak B. Theory and practice of Histotechnology, 2nd ed: Battelle Press, Ohio 1980; p. 282.

[22] Luna L, Manual of Histologic Staining Methods from the AFIP, 3rd ed: McGraw-Hill, New York 1968; pp. 162-163.

[23] Folkman J. Tumor angiogenesis. In: Cancer Medicine, 5th ed, London: Decker 2000; pp. 13-52.

[24] Norrby K. Mast cells and angiogenesis. APMIS 2002; 110(5): 35571.

[25] Sorbo J, Jakobsson A, Norrby K. Mast cell histamine is angiogenic through receptors for histamine1 and histamine 2. Int J Exp Pathol 1994; 75(1): 43-50.

[26] Norrby K, Sorbo J. Heparin enhances angiogenesis by a systemic mode of action. Int J Exp Pathol 1992; 73(2): 147-55.

[27] Ribatti D, Finato N, Crivellato E, et al. Neovascularization and mast cells with tryptase activity increase simultaneously with pathologic progression in human endometrial cancer. Am J Obstet Gynecol 2005; 193(6): 1961-5.

[28] Muramatsu M, Katada J, Hattori M, Hayashi I, Majima M. Chymase mediates mast cell-induced angiogenesis in hamster sponge granulomas. Eur J Pharmacol 2000; 402(1-2): 181-91.

[29] Qu Z, Kayton RJ, Ahmadi P, et al. Ultrastructural immunolocalization of basic fibroblast growth factor in mast cell secretory granules: morphological evidence for bFGF release through degranulation. J Histochem Cytochem 1998; 46(10): 1119-28.

[30] Reed JA, Albino AP, McNutt NS. Human cutaneous mast cells express basic fibroblast growth factor. Lab Invest 1995; 72(2): 215 22.

[31] Esposito I, Menicagli M, Funel N, et al. Inflammatory cells contribute to the generation of an angiogenic phenotype in pancreatic ductal adenocarcinoma. J Clin Pathol 2004; 57(6): 630-6.

[32] Pennington DW, Lopez AR, Thomas PS, Peck C, Gold WM. Dog mastocytoma cells produce transforming growth factor beta 1 . J Clin Invest 1992; 90(1): 35-41.

[33] Boesiger J, Tsai M, Maurer M, et al. Mast cells can secrete vascular permeability factor/vascular endothelial cell growth factor and exhibit enhanced release after immunoglobulin E-dependent upregulation of FC-epsilon I expression. J Exp Med 1998; 188(6): $1135-45$.

[34] Grützkau A, Krüger-Krasagakes S, Baumeister H, et al. Synthesis, storage, and release of vascular endothelial growth factor/vascular permeability factor (VEGF/VPF) by human mast cells: implications for the biological significance of VEGF206. Mol Biol Cell 1998; 9(4): 875-84.

[35] Holmstrup P, Vedtofte P, Reibel J, Stoltze K. Long-term treatment outcome of oral premalignant lesions. Oral Oncol 2006; 42(5): 46174 .

[36] Shintani S, Li C, Ishikawa T, Mihara M, Nakashiro K, Hamakawa $\mathrm{H}$. Expression of vascular endothelial growth factor A, B, C, and D in oral squamous cell carcinoma. Oral Oncol 2004; 40(1): 13-20.

[37] Shang ZJ, Li JR. Expression of endothelial nitric oxide synthase and vascular endothelial growth factor in oral squamous cell carcinoma: its correlation with angiogenesis and disease progression. J Oral Pathol Med 2005; 34(3): 134-9.

[38] Wong YK, Liu CJ, Kwan PC, Chao SY. Microvascular density and vascular endothelial growth factor immunoreactivity as predictors of regional lymph node metastasis from betel-associated oral squamous cell carcinoma. J Oral Maxillofac Surg 2003; 61(11): 1257-62.

[39] Sawatsubashi M, Yamada T, Fukushima N, Mizokami $H$, Tokunaga $\mathrm{O}$, Shin T. Association of vascular endothelial growth factor and mast cells with angiogenesis in laryngeal squamous cell carcinoma. Virchows Arch 2000; 436(3): 243-8.

[40] Tae K, El-Naggar AK, Yoo E, et al. Expression of vascular endothelial growth factor and microvessel density in head and neck tumorigenesis. Clin Cancer Res 2000; 6(7): 2821-8.

[41] Weidner N, Semple JP, Welch WR, Folkman J. Tumor angiogenesis and metastasis-correlation in invasive breast carcinoma. $\mathrm{N}$ Engl J Med 1991; 324(1): 1-8.

[42] Jin Y, Tipoe GL, White FH, Yang L. A quantitative investigation of immunocytochemically stained blood vessels in normal, benign, pre-malignant and malignant human oral cheek epithelium. Virchows Arch 1995; 427(2): 145-51. 
[43] Macluskey M, Chandrachud LM, Pazouki S, et al. Apoptosis, proliferation, and angiogenesis in oral tissues. Possible relevance to tumour progression. J Pathol 2000; 191(4): 368-75.

[44] Jippo T, Tsujino K, Kim HM, et al. Expression of mast-cellspecific proteases in tissues of mice studied by in situ hybridization. Am J Pathol 1997; 150(4): 1373-82.

[45] Tomita M, Matsuzaki Y, Onitsuka T. Effect of mast cells on tumor angiogenesis in lung cancer. Ann Thorac Surg 2000; 69(6): 168690 .

[46] Benitez-Bribiesca L, Wong A, Utrera D, Castellanos E. The role of mast cell tryptase in neoangiogenesis of premalignant and malignant lesions of the uterine cervix. J Histochem Cytochem 2001; 49(8): 1061-2.

[47] Marks RM, Roche WR, Czerniecki M, Penny R, Nelson DS. Mast cell granules cause proliferation of human microvascular endothelial cells. Lab Invest 1986; 55(3): 289-94.
[48] Meininger CJ. Mast cells and tumor-associated angiogenesis. Chem Immunol 1995; 62: 239-57.

[49] Walls AF, Roberts JA, Godfrey RC, et al. Histochemical heterogeneity of human mast cells: disease-related differences in mast cell subsets recovered by bronchoalveolar lavage. Int Arch Allergy Appl Immunol 1990; 92: 233-41.

[50] Folkman J, Taylor S, Spillberg C. The role of heparin in angiogenesis. Ciba Found Symp 1983; 100: 132-49.

[51] Irani AA, Schelter NM, Craig SS, et al. Two types of mast cells that have distinct neural protease compositions. Proc Natl Acad Sci USA 1986; 83(12): 4464-8.

[52] Pazouki S, Chisholm DM, Adi MM, et al. The association between tumour progression and vascularity in the oral mucosa. J Pathol 1997; 183(1): 39-43.

(C) Michailidou et al.; Licensee Bentham Open.

This is an open access article licensed under the terms of the Creative Commons Attribution Non-Commercial License (http://creativecommons.org/licenses/ by-nc/3.0/) which permits unrestricted, non-commercial use, distribution and reproduction in any medium, provided the work is properly cited. 